\title{
A SURVEY OF ACADEMIC LITERATURE ON CONTROLS OVER INTERNATIONAL \\ CAPITAL TRANSACTIONS
}

Michael P. Dooley

Working Paper 5352

\author{
NATIONAL BUREAU OF ECONOMIC RESEARCH \\ 1050 Massachusetts Avenue \\ Cambridge, MA 02138 \\ November 1995
}

This paper is part of NBER's research program in International Finance and Macroeconomics. Any opinions expressed are those of the author and not those of the National Bureau of Economic Research.

(C) 1995 by Michael P. Dooley. All rights reserved. Short sections of text, not to exceed two paragraphs, may be quoted without explicit permission provided that full credit, including () notice, is given to the source. 


\title{
A SURVEY OF ACADEMIC LITERATURE ON CONTROLS OVER INTERNATIONAL \\ CAPITAL TRANSACTIONS
}

\begin{abstract}
This paper reviews recent theoretical and empirical work on controls over international capital movements. Theoretical contributions reviewed focus on "second best" arguments for capital market restrictions as well as arguments based on multiple equilibria. The empirical literature suggests that controls have been "effective" in the narrow sense of influencing yield differentials. But there is little evidence that controls have helped governments meet policy objectives, with the exception of reduction in the governments' debt service costs, and no evidence that controls have enhanced economic welfare in a manner suggested by theory.
\end{abstract}

Michael P. Dooley

Department of Economics

Social Sciences I

University of California, Santa Cruz

Santa Cruz, CA 95064

and NBER 
A Survey of Academic Literature on Controls Over International Capital Transactions

July 7, 1995

Contents

I. Introduction and Plan of Study

II. Stabilization

1. Short-run stabilization of output and relative prices

2. Long-run stability of the regime: speculative attack models

3. Regime changes with perfect capital mobility

4. Regime changes with capital controls

5. Regime changes with maximizing models of the current account

6. Stabilization with price and wage flexibility 11

7. Stabilization of relative prices 13

8. Models of partial effectiveness 15

III. Medium-Term Second-Best Arguments 16

1. Fiscal implications of capital controls 16

2. Taxation of resident capital income 18

3. Uncertain property rights 20

4. Capital markets as a source of uncertainty 21

5. Domestic capital market distortions 22

6. Sequencing of liberalization of capital markets and trade in goods and services 23

IV. Multiple Equilibria and First-Best Arguments 25 
V. Evidence on Effectiveness and objectives of Controls 29

1. Direct measures of capital flows 34

2. Tests of the political economy of capital controls 35

3. Integration and net capital flows 36

4. Gross capital flows and capital controls: theory and evidence

Bibliography 


\section{Introduction and Plan of study}

The volume of international private capital transactions has increased dramatically in recent years both for developed and developing countries. The forces that have pushed private investors and borrowers into international markets include technological improvements that have reduced the cost of international financial intermediation as well as a reduction in government interference with such transactions.

The opening of international markets has also presented important challenges for policymakers. Recent examples include the series of crises that have beset the European Exchange Rate Mechanism since 1992, widespread capital inflows to emerging markets through early 1994 and, most recently, the turbulence in some developing country exchange and capital markets in late 1994 and early 1995 as these inflows were partly reversed. These events have raised questions concerning the social costs and benefits of private capital flows and government programs designed to limit or modify the composition of such transactions.

The private benefit from access to international capital markets for both savers and borrowers is a basic conclusion of welfare economics. Free capital movements tend to allocate capital to its most productive uses across countries and allow residents of different countries to engage in welfare-improving intertemporal consumption smoothing. In a competitive model with perfect foresight and complete markets, the welfare benefit from intertemporal trade is identical to the welfare benefit from international trade in goods and services. This general conclusion is not sensitive to the exchange rate regime (Helpman, 1981).

While this general result imposes considerable discipline upon the search for optimal limits on capital mobility, economic theory also suggests that exceptions to this general rule are possible in cases where preexisting distortions violate the assumptions necessary to support a "first best" competitive equilibrium. Such "second best" arguments are dealt with in an extensive literature reviewed below. The basic idea is quite simple. If the economy is assumed to suffer from one distortion, it is possible to improve welfare through the judicious introduction of another distortion.

The theoretical literature that is the raw material for a survey of "second-best" policy regimes naturally focuses on models in which government programs might generate welfare-improving interventions in international capital markets. Since there are, in principle, an infinite number of possible market failures, there are an infinite number of welfare-enhancing second-best capital control regimes. 
Many of the disagreements about the desirability of capital flows can be traced to different assumptions concerning the efficiency of private intertemporal decisions. While most economists argue that markets work well for static allocation of resources, there is a strong tradition of mistrusting so-called "speculative" behavior as being contrary to the collective interests of the community. This has led to proposals that range from "throwing sand in the wheels" of international capital movements to complete prohibition of such transactions.

An equally strong tradition that has influenced the literature is the view that government interventions in capital markets seldom accomplish their stated objectives. While there is a well-developed literature dealing with the economic effects of capital control programs, there has been very little work that attempts to relate observed capital control programs to specific government objectives.

The conclusion drawn here from this literature is that an ideal government dealing with one clear distortion could, in principle, improve welfare by intervening in international capital markets. This is not a policy recommendation, however, since the actual effectiveness of such a program is an empirical question. An easy, and perhaps wise way to avoid the empirical issue is to point out that it would be better to remove the existing distortion rather than introducing another to mitigate the damage inflicted by the first. The present paper will refrain from repeating this even in cases where this seems to be the obvious answer.

Not all arguments for government intervention in international capital markets are based on "second-best" considerations. A quite different exception to the general rule that government constraints on capital mobility are welfare reducing arises in cases where stable, multiple equilibria are predicted. If multiple equilibria are possible it follows that the "first-best" equilibrium might be attained or maintained through government intervention in capital markets. This is a much more recent contribution to the debate concerning capital controls and it is emphasized by proponents of capital controls to protect a fixed exchange rate regime during a transition to a monetary union. In reviewing these arguments below the paper aims to clarify the very special circumstances under which such theoretical arguments are valid. The paper also reviews recent attempts to relate these models to recent experience in Europe.

The first step in determining whether or not capital controls have been used effectively is to see if data support the proposition that controls have had a measurable effect on economic variables. There is an extensive literature on this issue and recent contributions are reviewed below. It is concluded from this literature that both developed and developing countries have succeeded in driving wedges between domestic and international interest rates. Moreover, governments seem to have used controls in concert with various forms of financial repression to generate revenue and limit debt service payments on domestic government debt. The power of control programs 
to affect other important economic variables such as the volume or composition of private capital flows, changes in international reserves, or the level of the exchange rate is, however, generally not supported by the data.

One important lesson that can be drawn from this work is that there is considerable evidence that capital control systems have not prevented successful speculative attacks on fixed exchange rate systems. The obvious problem here is that in cases where a discrete parity change is expected, the yield differentials that can be generated by control programs are quite small as compared to the capital gains available to private investors that correctly anticipate a parity change. This is fully consistent with a variety of theoretical models of speculative attacks surveyed below. There is some evidence that controls prolong the life of the regime. Unfortunately very little is known about the timing of speculative attacks with or without control programs, so it is difficult to evaluate the view that control programs "buy time" while the government comes to grips with its policy conflicts.

The literature has generally not focused on the question of whether or not observed capital control programs actually mitigate the effects of welldefined distortions. Giavazzi and Giovannini (1989), for example, conclude that, "The widespread use of capital controls is not clearly justified by any widely agreed-upon economic theory; indeed to our knowledge, there have only been a very few attempts to study capital controls using explicit second best arguments" (page 162). Some very recent work on the political economy of capital controls has begun to ask the question of what types of distortions seem to motivate existing control programs. Preliminary findings reviewed below suggest that governments have used controls over extended time periods to limit the cost of debt service and to maintain a tai base for inflation and financial repression.

The more important question of whether the costs of the distortions generated by controls outweigh potential benefits has not yet been addressed. A very informal test of this proposition is that enthusiasm for such programs seems to be inversely related to the observer's experience with trying to formulate and enforce a set of administrative rules that have as their objective preventing participants in financial markets from maximizing the private returns.

A familiar analogy drawn from international trade theory is an "optimal tariff" which might exploit a country's market power over production of its exports. Such arguments for government intervention are clearly "correct" given the assumptions. Nevertheless, no one in recent memory has suggested that government could or should attempt to adopt such a tariff. All of the standard arguments against the practical usefulness of an optimal tariff on exports apply with equal force to taxes or quantitative controls on intertemporal trade, that is, trade in financial assets. These include the possibility of retaliation by other countries, evasion, administrative costs, inability to quantify the distortion, and therefore the appropriate 
tariff, the political temptation to intensify the preexisting distortion, and finally the possibility that the protected industry will "capture" the political machinery that sets the tariff.

A topic that deserves more attention is what might be called the public choice approach to controls. The idea here is that control systems once established are likely to take on a life of their own as the control bureaucracy and its constituency attempts to maximize its own power and wealth. Thus, controls designed to mitigate a temporary distortion might outlive the economic rationale on which they were established. Further, private investors that have invested heavily in avoiding the control mechanisms are likely to welcome the protection from other investors that have not done so. Cairncross (1973), for example, argues that the British capital control system that evolved from a comprehensive system of e:change controls during the second world war survived long after the original rationale was relevant. Moreover, he argues that by the early 1970s the "bite" of controls was very uneven across investors because certain types of transactions were exempt from controls. Dornbusch (1986) argues in favor of controls under some circumstances but points to an example where the control system had outlived its usefulness and had become the problem rather than the solution.

There is a very large academic literature dealing with the economic effects of legal restrictions on private capital flows. This survey organizes this body of work according to the apparent objectives that might justify such restrictions. Section II of the survey examines models that relate controls to the ability of monetary and fiscal policy to stabilize output, prices, or the real exchange rate. The implicit assumption in this literature is that governments have good reasons for using these policy tools and that they do so in a welfare-improving manner.

Section III considers a variety of distortions to a competitive equilibrium that might make a control program optimal. These include provision of a tax base in an optimal fiscal regime, a means to counteract distortions that limit domestic capital formation, and a means to insulate the economy from destabilizing capital flows.

Section IV considers a very different rationale for restrictions on capital flows. In these models multiple competition equilibria are possible and controls might be useful in maintaining a good equilibrium or in moving from a low to a high welfare equilibrium.

Section $V$ considers the empirical evidence on the effectiveness of controls. It also examines recent work that relates the use of controls to characteristics of individual countries. 


\section{Stabilization}

1. Short-run stabilization of output and relative prices

The classic framework for evaluating the implications of capital mobility and the effects of limiting capital mobility is the MundellFleming model of a small open economy. In commenting on Williamson's (1993) review of the policy issues associated with recent private capital inflows, Branson (1993) notes that while a description of the stylized facts is useful and interesting, it is difficult to evaluate the policy options in the absence of a generally agreed upon theoretical framework. The framework suggested by Branson is the familiar Mundell-Fleming model. This paper shares the view that lessons about capital mobility drawn from simple versions of the model have proven remarkably robust to subsequent theoretical refinements and empirical evidence. In the remainder of this paper it is argued that the role of capital controls in stabilization policy is only part of the story, but it is a potentially important part. It follows that this is a good place to start an evaluation of what the academic literature has to offer in evaluating policies that affect international capital movements.

The Mundell-Fleming tradition starts from the implicit assumption that policies designed to stabilize economic activity are useful and welfare enhancing. The working assumption is that the government values the ability to "distort" domestic spending decisions by manipulating the real interest rate in order to influence the growth in output and perhaps the rate of inflation. In this literature the primary existing distortion is slow adjustment of nominal wages and prices. It follows that the assumption of flexible nominal prices (nominal prices, wages, exchange rates, and interest rates) eliminates the distortion and the rationale for welfare-improving capital controls. Such a model is considered in the next section.

If capital is free to move across national borders and the nominal exchange rate is fixed or heavily managed, the government loses control over domestic monetary conditions. If the exchange rate is not managed, monetary policy might still be constrained by incipient capital movements, since changes in domestic interest rates can generate large changes in nominal and real exchange rates. While this ensures a powerful transmission mechanism for monetary policy, governments might consider the resulting large changes in relative prices as a constraint on monetary policy. Flexible exchange rate models are reviewed below.

In contrast, fiscal policy is a powerful tool for stabilizing domestic output even if capital markets are highly integrated. It follows that if stabilization policy is welfare-improving, increased capital mobility generated by a relaration of capital controls should be followed by assigning fiscal policy to domestic stabilization. 
This framework provides a simple criterion for the optimality of capital account restrictions. If another policy tool is available for assignment to domestic stabilization, it might be optimal to open the capital account. Thus, Branson (1993) argues that existing capital controls imply that the government faces constraints on the exercise of fiscal policy for stabilization. It follows that removal of capital controls may not be optimal unless the constraints on the effective utilization of fiscal policy are first eliminated.

The well-known arguments reviewed above start from the proposition that wages and prices fail to clear markets and that this generates the rationale for stabilization policy. In an early attempt to better understand the nature of the sticky price distortion Flood and Marion (1982) develop a model in which labor contracts generate inertia in wages. They then see if capital controls in the form of a dual foreign exchange market can minimize the variance of employment in the face of a variety of shocks to the system. They also show that the labor contracts chosen by the private sector depend upon the policy regime in place, including the controls on capital flows. It follows that a full evaluation of the welfare implications of capital controls should consider the private reaction to the removal of controls. In some cases the "preexisting" distortion may be an endogenous response to the controls themselves. This is one of a very few attempts offered in the literature to deal with the well-known Lucas critique of analyses that attempt to predict the economic effects of policy changes without explicit consideration of how the private sector's behavior is likely to change in response to the regime change.

\section{Long-run stability of the regime: speculative attack models}

Early contributions to analysis of capital controls using the MundellFleming model focused on dual exchange rate regimes (Argy and Porter, 1972; Eleming, 1974; Lanyi, 1975). These models show that effective segregation of financial and current account transactions, with no official intervention in the financial exchange market, is equivalent to the prohibition of net private capital flows. These authors suggested that such a control might be only partially effective, but even if fully effective, the Mundell-Fleming model does not predict that controls over capital flows can sustain an inconsistent policy regime forever. Effective capital controls alter the channels through which the private sector responds to changes in the economic environment. Thus, effective controls alter the mechanism through which an inconsistent regime is forced to collapse but not the eventual result. A straightforward extension of the Mundell-Fleming framework allows a better understanding of the process by which an inconsistent policy regime comes to an end with or without capital mobility. 
3. Regime changes with perfect capital mobility

Krugman (1979), Flood and Garber (1984), provide models of speculative attacks against inconsistent policy regimes. 1/ The inconsistency is that the government sets a rate of growth for the domestic assets of the central bank in order to finance a fiscal deficit which is inconsistent with the fixed nominal exchange rate and the growth in the demand for money. With perfect capital mobility and purchasing power parity, the demand for real money balances is predetermined so that increases in the domestic part of the monetary base are instantly offset by changes in international reserves. When the central bank's international reserves fall to a certain level it is known that the central bank will witharaw from the foreign exchange market and the currency will float freely.

This regime comes to an end when speculators calculate that a successful attack will generate a discrete depreciation of the currency. Competition among the speculators will force the speculative attack to occur at a point where no expected profit is possible. While quite simple, the model has the important feature that no apparent change in the fundamentals occurs at the time of collapse. Nevertheless, the private capital flows that generate the collapse are driven by fully rational interpretation of the fundamentais.

\section{Regime changes with capital controls}

The key feature of capital controls in the context of a speculative attack model is that the private sector can no longer trade private debt for foreign exchange and, in turn, trade the foreign exchange for domestic money. With capital controls, the private sector can adjust its money holdings but only through net transfers of goods and services to the rest of the world. A more complete evaluation of the effects of capital controls therefore requires a model of the current account. Because the private sector's willingness to distort their consumption over time is probably limited, effective capital controls might considerably extend the life of an inconsistent regime.

Several authors have incorporated a partial equilibrium model of the current account into the monetary models discussed above in order to study the long-run effects of capital controls. If changes in domestic absorption are assumed to be a fraction of changes in output (an implication of a simple Keynesian consumption function), any permanent (temporary) increase in demand "causes" a permanent (temporary) increase in the trade deficit. Moreover, if the Marshall-Lerner conditions are satisfied, a real depreciation of the exchange rate "causes" a reduction in the trade balance.

1f For a recent review of the literature that followed see Garber and Svensson (1994). 
Using these partial equilibrium assumptions, it is straightforward to determine the long-run response of the system to a shock such as an increase in the money stock or government spending.

Delbecque (1993) develops a model of a dual exchange rate system that captures these interactions. In this model all private capital transactions are effectively limited to the financial exchange market. Since the government does not participate in this market, net private capital flows are necessarily zero. Current account transactions are permitted in the commercial exchange market. The government intervenes to fix the exchange rate in this market.

An important implication of this model is that private net intertemporal trade in goods and services is matched by a secular change in the government's net international reserves. The general point is that the government acts as a "financial intermediary" for the private sector in a system with capital controls. Thus, the model is closed by an assumption that the government cares about its stock of net international reserves. The inconsistent policy settings cause a deterioration of the current account that eventually exhausts the government's stock of international reserves.

Gros (1992) also models speculative attacks but points out that while capital controls can limit private sector speculation in most cases, governments are forced to augment the capital controls program with domestic interest rates that are much higher or lower than would be the case in the absence of speculative pressure. An important aspect of this framework is that controls are effective but can be overcome at some cost to the speculator. In this setup the government's commitment to maintain the peg can be easily monitored by the private sector since it is revealed in interest rate policy. When the government reveals that it is unwilling to sacrifice control over domestic interest rates, the private sector will know that a small speculative attack, and the associated low costs of avoiding the capital control program, will be successful.

The welfare effects of controls are not well defined in these models. The intuition, however, is clear. If the additional time during which the regime survives is used wisely in the sense that consistent policies are introduced, the measure of policy independence generated by the control program might be welfare improving.

The models reviewed above are designed to clarify the dynamics of a speculative attack on an inconsistent regime but do not provide insight as to why a rational government would pursue such a policy. Wyplosz (1986) develops a similar model and argues that capital controls that are only temporarily effective nevertheless make an adjustable peg regime viable. In this framework the authorities operate a monetary policy which is inconsistent with permanently fired exchange rates but overcome this potential 
inconsistency with discrete changes in the exchange rate peg. Wyplosz points out that capital controls play a crucial role in making such an adjustable peg system work.

The key to the argument is that the volume of private capital flows in response to an expected profit opportunity is limited by the capital control system. In this model controls are modeled so that residents of the country cannot change their holdings of foreign assets or their financial liabilities to nonresidents. Nonresidents are assumed to hold domestic money, for transactions purposes, and are free to sell these against foreign currency at the commercial exchange rate.

The crisis in this model comes when nonresidents believe that selling off all their holdings of domestic money will trigger a devaluation or revaluation of the nominal exchange rate. At this point the central bank announces a discrete change in the parity. Wyplosz does not attempt to assess the optimality of such a system although the desire to reduce the short-run variance of exchange rates, discussed below, would provide a rationale.

5. Regime changes with maximizing models of the current account

The partial equilibrium approach to modeling the current account described in the previous section clarified the important point that capital controls shift private adjustment from capital flows to the current account. A weakness is that the private sector is rearranging its intertemporal consumption in response to incentives created by the government policy, but there is no forward-looking theory for why this might be optimal.

Econometric evidence does support the view that over a time horizon of a year or so movements in the current account are dominated by relative rates of income growth and relative prices. But over longer time horizons the outstanding stock of debt begins to play a dominant role. In general, the simple model is not well suited to dealing with issues associated with increases in indebtedness over time.

The modern literature on the macroeconomic effects of capital controls focuses on these long-run effects. 1/ Moreover, by including expectations about the long run as determinants of current economic behavior the modern literature provides a link between capital mobility and observed short-run behavior of the economy and how it is affected by controls over capital flows.

Calvo (1987) develops a model that addresses the issue of the behavior of the private sector in a regime that is known to be inconsistent and where it is known that the regime will be abandoned when the government exhausts its international reserves. The model has the same building blocks as the

1/ See Obstfeld and Rogoff (1994) for a recent review. 
speculative attack models discussed above except that the current account is explicitly modeled. The model predicts, in cases where a successful speculative attack is expected, that the public will increase its consumption (a current account deficit) until the date of the regime change and then will decrease consumption (a current account surplus) thereafter. The financial counterpart of this leading up to the regime change is, of course, a decline in the government's net international reserve assets.

The key to this result is the condition that after the attack, revenue from inflation must rise to balance the fiscal budget. As the higher rate of actual and expected inflation optimal real money demand falls, the real marginal utility of money balances falls, and so the marginal utility of consumption just before the crisis must also be less than the marginal utility of consumption just after the crisis. The model is also extended to consider the effects of anticipated real ezchange rate changes.

This type of model clarifies the fact that a distortion in the time profile of consumption is suboptimal, and so there must be some offsetting benefit of prolonging the life of the inconsistent regime.

Park (1994) provides a maximizing model in which households adjust their intertemporal consumption of goods and real money balances in order to maximize expected utility over an infinite planning horizon. He asks if a liberalization of the capital account can generate an immediate speculative attack on a fixed exchange rate regime. The model suggests that initial conditions are crucial to the answer. If the domestic real interest rate is initially below the world interest rate, the initial result of liberalization is an incipient net capital outflow and a rise in the domestic real. interest rate. The increase in debt service cost of the government's domestic debt is assumed to be met by an increase in the growth of domestic assets in order to finance the resulting fiscal deficit.

If the liberalization is a surprise, foreign and domestic expected yields equalize immediately and if a speculative attack is expected to be successful, the private sector reduces its demand for real money balances because of the higher rate of inflation that follows the successful attack. The resulting sale of domestic assets to the central bank might exhaust its reserves and generate an immediate attack and regime change. If the fixed exchange rate is initially sustainable, a secular fall in reserves is anticipated and eventually a successful speculative attack similar to those discussed in the previous section.

Auernheimer (1987) compares the breakdown of inconsistent regimes in a maximizing model with and without capital controls. The model suggests that with capital mobility it makes no difference if the government chooses an inconsistent exchange rate or monetary rule in the onset of the crisis. However, like Calvo, he shows that with capital controls the inconsistent regime generates lasting suboptimal real effects on the current account. 
In general, these models reinforce the lessons from the partial equilibrium model discussed above. Even perfectly effective controls on private capital transactions can at best extend the life of an inconsistent policy regime. They add the important conclusion that the path for consumption is suboptimal during the interval for which the regime survives and this distortion continues after the inconsistent regime has ended.

\section{Stabilization with price and wage flexibility}

The relevance of sticky prices for very short-run evaluation of policy effects in industrial countries is widely accepted and built in to standard econometric models. The relevance of the results depend, of course, on the assumption that monetary policy, in fact, is effective in overcoming the distortions generated by inflexible prices.

Economies that have been subjected to high inflation are often highly indexed. In these economies it has become conventional to assume that monetary policy has very limited power to stabilize real output, even in the short run. Models developed to understand these economies generally assume that real output is independent of monetary policy and the fiscal deficit. These models focus on the role of capital controls in determining the private sector's response to economic shocks with and without the ability to borrow and lend in international credit markets.

An important extension of the Mundell-Fleming model introduces domestic price and exchange rate flexibility. In this version of the model, with perfect capital mobility and flexible exchange rates, changes in the domestic money stock generate proportional changes in all nominal prices so that the stabilization role for monetary policy disappears, and so too do the associated arguments for capital controls. If the private sector's consumption decisions are forward looking, and a number of other conditions are met, Ricardian equivalence also eliminates the effects of bond-financed fiscal deficits. Government spending has real effects but is not useful in generating welfare-increasing changes in the level of employment.

Because effective or even partially effective capital controls push all or a part of the adjustment to shocks to the system to the current account, that is, to net sales of goods and services to nonresidents, it follows that capital controls alter the response of the economy to policy actions. In general the neutrality of policy discussed above is overturned.

The discussion now turns to papers that address the question of how capital controls affect the relationship between monetary and fiscal policies and other economic variables in a model with flexible prices. It should be noted that in these models there is no presumption that the effects of controls are welfare improving. Instead, the objective is simply to understand the interactions of policy shocks and other shocks to the system in a second-best world. 
Reinhart (1991) examines the effects of a ta: on foreign assets in a model of flexible exchange rates with asset accumulation. In such an economy the private sector's accumulation of foreign assets is constrained by the current account balance. The model considers the effect of the ta: on government revenues, the evolution of asset stocks and the dynamics of the real exchange rate. The main conclusion is that the imposition of capital controls in the form of a tax on foreign assets generates a temporary trade deficit and an appreciation of the real exchange rate.

Adams and Greenwood (1985) offer a maximizing model of intertemporal consumption for an open economy and explore the welfare effects of capital controls. The model develops several general points that will be important in all the literature to be reviewed below. First, the model shows that dual exchange regimes are equivalent to a program of taxation of capital movements. Second, some program of quantitative restrictions on capital movements is equivalent to a system of taxes or dual exchange markets. Third, any effective capital control program can be manipulated to attain the government's target for the current account balance. Finally, the welfare losses generated by such regimes are analogous to those associated with restrictions on temporal trade in goods and services.

This last point is an important result. In an intertemporal marimizing model with flexible prices, goods available to households at different points of time are analogous to different goods available at a point in time. Just as distortions of relative prices at a point in time are usually welfare reducing, distortions of relative prices of the same good at different points of time--where the relative price is an interest rate--are also usually welfare reducing. Optimal capital control programs in such models are possible only in cases where there is some preeristing distortion to interest rates or if private expectations are systematically incorrect.

Greenwood and Kimbrough (1985) present a model that allows an evaluation of the effects of capital controls in a world where identical households maximize intertemporal utility with perfect foresight and monetary policy has no effects (the monetary sector is not explicitly modeled). In this model the role of capital controls in limiting the public's ability to trade intertemporally is highlighted.

An interesting feature of the model is that in the absence of capital controls, fiscal deficits have no effect on the equilibrium because households anticipate future tax liabilities. But with capital controls, sales of government debt to the rest of the world are equivalent to a relaration of the government's prohibition of private capital flows. Moreover, since the public regards the government's debt as equivalent to their own, the government is a perfect financial intermediary.

The model also clarifies the likely co-movement of real macroeconomic aggregates with and without capital controls. If capital markets are integrated, real interest rates must move together across countries in response to a shock to the system and, in general, real output across 
countries will also be positively correlated. Capital controls imply that real interest rates can be negatively correlated and, in turn, output and other aggregates might be negatively correlated. The model suggests that capital controls provide a measure of insulation from foreign fiscal shocks.

Guidotti and Vegh (1992) present a model of a large open economy that adds a monetary sector to the model discussed above. They start from the proposition that with perfect capital mobility domestic disturbances have no real effects. In part this is due to the result that the world money supply is immediately redistributed through international capital flows following a disturbance. With capital controls, money holdings can be redistributed only as the mirror image of current account imbalances. The real effects of these imbalances are felt at home and in the rest of the world. Moreover, important variables such as real interest rates, relative prices, and consumption are affected. Their model suggests that unanticipated and permanent changes in domestic monetary and fiscal policies affect consumption, real interest rates, and the real exchange rates.

\section{Stabilization of relative prices}

The effects of capital flows on relative prices or real exchange rates has been at the center of much of the literature concerning the economic effects of capital mobility. A stylized fact associated with liberalization of controls over capital flows among developing countries is that the resulting adjustment includes substantial appreciation of the real exchange rate. This, in turn, may be an undesirable feature of an open capital market if temporary relative price changes and associated allocations of productive resources are welfare reducing. Krugman (1987), for example, argues that temporary real appreciation of the exchange rate might permanently injure export industries if hysteresis is a feature of the correct dynamic model of the economy.

Several authors have suggested that capital mobility should be limited until policies designed to offset the real exchange rate changes are in place. The obvious choice to combat the effects of a capital inflow, for example, would be a reduction in government spending. In this section it is argued that the welfare implications of these models are far from clear. Moreover, formal explanations of a relationship between capital market liberalization and real exchange rate instability can be generated by very different models.

In the spirit of the sticky price framework, a way to understand a link between liberalization and real exchange rate appreciation is to appeal to a model in which nominal shocks generate overshooting of nominal exchange rates and therefore changes in real exchange rates. Sussman (1992) uses a version of the Dornbusch overshooting model to help explain an apparently unsuccessful liberalization of the capital account in Israel in 1977. Liberalization of the capital account in this model takes the form of eliminating controls that had supported a tar on domestic asset yields and 
domestic bank loans. Sussman presents evidence that controls in place generated large differentials between on- and offshore lending and deposit rates in Israel before and after the brief experiment with liberalization.

The model predicts that the reduction in the tar on loans increases investment and aggregate demand and, according to the model, creates an inflationary shock to the system. In addition, the elimination of the tar on domestic assets generates a decline in the demand for money. Since this is equivalent to an increase in the money supply, the model predicts that the domestic nominal interest rate will at first fall, prices will start to rise, and to satisfy the rational expectations interest parity condition, the nominal exchange rate will depreciate by more than the steady state amount.

The lesson from this model is that the liberalization itself generates an inflationary shock for the economy and a temporary distortion of the prices of traded and nontraded goods. Clearly, an appropriate fiscal policy response could minimize the damage. But if the fiscal system is unable to respond, perhaps because the elimination of the subsidy for government borrowing makes a contractionary fiscal shock impossible, the liberalization will involve short-run costs.

A very different way to introduce real exchange rates into a model is to assume that prices are flexible but to introduce more than one good. Van Wijnbergen (1990) develops a model in which the imposition of a tay on capital imports lowers domestic real interest rates and raises the world real interest rates. In turn, current consumption is shifted from goods consumed by residents toward goods favored by nonresidents today, with a reversal of this shift in the future. The change in the composition of current and future demands in turn generates a depreciation of the home currency now and an expected appreciation later.

A useful framework developed by Edwards (1989) considers an export good, an import good, and a nontraded good. The relative price of exports and imports is the terms of trade. The relative price of exports and nontraded goods is usually identified as the real exchange rate. In such a model, capital flows related to liberalization of the capital account can generate real exchange rate changes since excess demand for the nontraded good can increase its nominal price while the price of the traded good is determined in world markets.

Edwards and Ostry (1992) present a model in which endogenous changes in relative prices of traded and nontraded goods interact with capital controls to affect welfare. The basic idea exploited in these models is that distortions in relative prices that are expected to change over time due to temporary policies generate distortions in the "consumption rate of interest" faced by households. The resulting intertemporal distortion of consumption can be magnified or mitigated by capital controls. 
The specific analysis of individual shocks to the system appears to be quite model specific, but the general point is important. Anticipated changes in relative prices alter the "interest rate" relevant for intertemporal consumption and investment decisions. Capital controls also alter intertemporal consumption and sectoral investment decisions. The main message here seems to be that real exchange rate changes associated with shocks to the system (e.g., terms of trade shocks) might be an important part of a comprehensive evaluation of the effects of capital controls.

This idea is developed further by the introduction of a temporary or variable labor market distortion in the form of a minimum real wage. This distortion generates a variable and suboptimal level of employment. Depending on a number of factors, a subsidy to foreign borrowing for tax on foreign lending) could tilt demand toward time periods during which unemployment is relatively high and, in turn, improve welfare.

This model is interesting because it abstracts entirely from monetary phenomenon yet still manages to find a second-best role for capital controls in promoting employment. The lesson, however, is that the level of ingenuity to which the modelers have to resort to create an intertemporal distortion to consumption and employment that can be offset by another intertemporal distortion, capital controls, seems to make the practical importance of the argument remote.

Another potential source of distortions of relative prices are temporary policy reforms, or permanent policy reforms that are expected to be temporary. Calvo (1988) argues that capital movements might magnify the distortion generated by temporary, changing, relative prices generated by changes in commercial policies.

\section{Models of partial effectiveness}

The idea that capital controls have important economic effects because they move adjustment into the international markets for goods and services has led many authors to consider mixed systems in which controls on capital movements are only partially effective. The intuition is that distorting intertemporal trade and consumption is costly to the private sector and so it is worthwhile to invest in techniques to avoid controls. It follows that the decision of how to model a capital control regime is an important issue in itself.

At one end of the spectrum are models that assume complete effectiveness. In these models there is no arbitrage of international interest differentials. In dual exchange rate models, for example, the spread between the commercial exchange rate and the financial exchange rate adjusts to equalize expected yields on domestic and foreign bonds. It is easy to show that the assumption of complete separation of the commercial and financial exchange rate markets is exactly equivalent to an effective prohibition of all net capital market transactions or an interest equalization tax that results in zero net trade. 
Such models have been criticized on the grounds that real world controls are never completely effective. An alternative specification is that controls are effective but can be avoided at a cost. This model is appealing because it seems to explain the empirical finding that the ability of controls to force a wedge between expected yields on securities issued in different countries seems to erode over time.

Bhandari and Decaluwe (1987) and Gros (1987, 1988) have emphasized the endogenous response of speculators to the incentive to avoid exchange controls. Gros (1988) assumes an increasing one-time cost faced by an investor who wishes to acquire foreign assets or liabilities. This model has the property that the long-run interest differential will be zero but during an adjustment period relative interest rates can be influenced by policy.

Giavazzi and Giovannini (1989) develop a model in which private sector traders are permitted to acquire a stock of foreign financial assets or liabilities equal to some fraction of the annual flow of their gross exports or imports of goods. Such positions are often referred to as leads and lags and are typically exempt from capital control programs. The idea here is that controls are effective but allow traders to utilize traditional forms of trade finance as long as the size of such transactions and their term to maturity conform to the usual parameters.

They show that in a maximizing model, such controls distort intertemporal trading patterns and have long-run effects on the economy. The cost of avoiding capital controls in this model is related to the cost of switching domestic production to export markets beyond what would be the competitive equilibrium.

The effectiveness of controls and the possible real distortions to trading patterns generated by avoidance, are of considerable practical importance in any decision to impose, modify, or remove a control regime. Indeed, the formal models of the economic effects of capital controls developed above are of little relevance if the private sector easily avoids such restrictions on their financial transactions. This is essentially an empirical question that is taken up below.

\section{Medium-Term Second-Best Arguments}

\section{Fiscal implications of capital controls}

This section departs from questions of short-run stabilization and focuses on interaction between capital controls and a variety of distortions that might justify such policies. The first example is motivated by the observation that controls over capital outflows are frequently designed to prevent erosion of the taz base for financial repression and inflation. Empirical evidence seems to support the view that governments that employ capital controls have higher rates of inflation, higher revenue from 
inflation, and lower domestic real interest rates as compared to countries that do not employ controls. If controls are effective in maintaining a ta: base, their removal implies a reduction in government revenue and therefore a presumable costly change in another variable that influences the fiscal deficit.

Giovannini and de Melo (1993) argue that the benefits from financial liberalization emphasized by McKinnon (1973) should be compared to the potential costs in terms tightening government revenue constraints. They provide a direct ex post measure of the differential borrowing costs on domestic and international debt of developing countries. The data supports the view that financial repression is a significant source of revenue for many of these countries.

Dornbusch (1988) offers a model in which the government faces two "fiscal" problems that explain the widespread use of capital controls. First, the government's existing domestic debt service is kept below what would be charged on world capital markets by restricting private capital outflows and thus depressing the domestic real interest rate. Second, in the absence of the implicit subsidy generated by controls over capital outflows, the government would be forced to choose revenue from inflation as the best alternative for meeting higher real debt service costs. Similar results are derived from an overlapping generations model developed by Sussman (1991).

Aizenman and Guidotti (1994) argue that collection costs associated with taxes other than the inflation tax might make capital controls a part of an optimal tax system. The model assumes that the government must service a domestic debt and must use a domestic tar on output that involves increasing costs of collection. The capital control they have in mind is a tax on foreign capital income and they assume the tax is not avoided. An interesting feature of the model is that the tax base for the foreign income tax is not only the private sector's stock of foreign assets but also the entire domestic debt. The domestic debt is relevant because the tax on foreign income drives a wedge between the foreign interest rate and the domestic interest rate. This, they argue, is equivalent to taxing private holdings of government debt, but unlike other taxes this one involves no collection costs. They show that countries with large stocks of domestic debt tend to utilize capital controls.

Drazen (1989) shows that the inflation tass is an important source of revenue for several European countries. He also shows that high inflation rates are only part of the story since these countries also have unusually high inflation tax bases in the form of bank reserve ratios. If residents of these countries could freely utilize offshore financial intermediaries this tax base would erode. It follows that capital controls are an important part of a fiscal system that relies heavily on the inflation tax. Drazen also argues that while such a system might allow the government to 
avoid even more distorting taxes in the short run, taxing savings and investment will in general lead to slower growth and reduced government revenues in the long run.

Brock (1984) provides an interesting counterargument. He points out that while opening the capital account can generate a decline in the inflation tax base, the government can offset this effect through reserve requirements on capital inflows or through prior import deposit schemes. This is an interesting argument because it suggests that a government with a fiscal problem can open the capital account and minimize the associated loss of revenue from inflation by expanding the inflation tax base.

This is one of the arguments for capital controls that seems quite sensitive to the assumption that the existing shortcomings in the tar system are unrelated to the existence of the controls. In particular, it seems quite likely that a government that imposes controls over capital outflows for some other reason will be tempted to exploit the revenue from financial repression that the controls make possible.

\section{Taxation of resident capital income}

Another longer run feature of some capital control programs is that they are designed to limit secular private capital outflows. It is often argued that countries with relatively low capital-labor ratios--developing countries and countries in transition--should offset a variety of domestic distortions that induce private investors to prefer foreign investments even when the expected private yields on domestic investment exceeds the private expected return in world capital markets. There are alleged to be many such distortions.

An obvious potential distortion is taxation or expected taxation of capital income generated within the country while foreign-based capital income cannot be taxed. If capital is mobile, such an optimal tar generates private capital outflows and a deterioration of the tax base, and underinvestment in the domestic capital stock. A limit to capital outflows, or the equivalent interest equalization tax, allows the government to tax capital at the appropriate, second-best, rate.

Razin and Sadka (1991) argue that empirical estimates of capital flight from developing countries suggest that governments cannot tax resident's income from foreign capital at the same rate at which they tax domestic capital income. In their model it is optimal for the government to restrict capital outflows if it cannot tax foreign assets. Dooley and Kletzer (1994) argue that simultaneous gross capital inflows and outflows are frequently the response of private investors to a variety of government guarantees and subsidies. If it is not possible for the government to credibly refuse to grant subsidies and guarantees, quantitative restrictions on some capital inflows and outflows can be welfare improving. 
Several papers written after the 1982 debt crisis take up the general issue of the optimality of external debt in the face of country risk. Since individual debtors within a country are interdependent in their ability to make debt service payments, and the government can prevent private debtors from making debt service payments, it might be that some collective (government) tax or subsidy to external borrowing is appropriate.

Harberger (1986) presents a model in which country risk generates a risk premium that grows with a country's external debt. This raises the possibility that the marginal cost of additional debt might exceed the average cost and that individual debtors may not internalize the social cost of their borrowing decisions. An important assumption in this model is that default carries costs to the debtor that are not at the same time benefits to the lenders. Under these plausible circumstances, a tax on capital inflows would be optimal.

Aizenman (1990) develops a model in which different attitudes toward default between the debtor country government and the debtor country private sector generates a distortion for domestic capital formation. In this case it is assumed that the government is known to discount the future at a higher rate as compared to households. This reflects the appealing idea that elected governments may be too interested in the next election. In this environment, domestic investment will be suboptimal since the government will discount the penalties associated with future default too heavily. The result is that private returns will exceed the world rate of interest by a political risk premium. In this environment, the government should subsidize investments in traded goods industries since this increases the vulnerability of the country to penalties for default and therefore increases the credibility of the government's promise not to default.

A somewhat different argument is advanced by Dellas and Galor (1992). In this paper, households located in a number of small open economies make saving and investment decisions that generate a stable but low steady state level of income and welfare. There is no incentive for capital flows among these economies since the return on capital is the same. A government that can accomplish transfers across generations can engage in external borrowing that can move the economy to another stable growth equilibrium, and, through appropriate transfers, increase welfare in all generations. As a part of the external borrowing program it is also necessary that offsetting private capital outflows be limited through a capital control program. The intuition behind this argument is appealing. Since investment in growth benefits future generations the present generation might invest at a suboptimal rate. If a government has the tools and wisdom it might be possible that a superior equilibrium can be attained if the government borrows on international capital markets. During the transition it is necessary to prevent private capital outflows that the current generation will find optimal. 


\section{Uncertain property rights}

Another argument develops the idea that "property rights" are often poorly defined in developing countries and perhaps even more so in formerly planned economies undergoing massive privatization programs. In effect this allows interest groups of private residents to "tax" or appropriate the capital income of both resident and nonresident investors. In contrast, investments abroad by residents of these countries are difficult for other residents to detect and appropriate. This leads to overinvestment in the "technically inferior" foreign capital stock in order to avoid the political risk associated with investment in a poorly organized country. In such an environment capital controls might be optimal.

Tornell and Velasco (1992) develop a formal model in which poorly defined property rights imply that investors will prefer external investment even if domestic investments have a higher social but lower private expected return. This model also demonstrates the less obvious point that capital controls may not improve welfare even if capital outflows are reduced. The reason is that the threat of free capital mobility might reduce the amount of appropriation by interest groups.

This is a subtle and important point for all second-best arguments. In a complete model it is not enough to show that a capital control can offset another distortion. It must also be shown that the existence of controls does not generate even more of the initial distortion. In the Tornell and Velasco model, it is natural to consider the endogenous response to the capital controls because it involves the behavior of private interest groups who must worry about reactions to their behavior. In the more common case where the government introduces the initial distortion "for a good reason" it is difficult or impossible to evaluate the possibility that the government will be tempted to exacerbate the initial distortion.

Alesina and Tabellini (1989) provide a model in which the initial distortion is the result of behavior of the government. In this model an alternating sequence of political parties, one representing labor and the other capital, appropriate capital income or labor income in order to make transfers to their constituency depending on the random outcome of elections. Since neither party can precommit to refrain from appropriation of income, capital controls will be necessary to prevent underinvestment in domestic capital.

This model also explains private capital flight in time periods when the government is borrowing on international capital markets. The model assumes that the government borrows a fixed amount per time period. In the absence of capital controls, residents, in turn, export capital in an effort to avoid taxation in the event its party is forced from office. This is one

of the very few formal models that explains simultaneous private capital outflows and government borrowing. The interesting feature of such a model 
is that the change in the private sector's foreign assets is not constrained by the current account imbalance. In fact, the private sector is constrained only by the government's willingness and ability to borrow.

\section{Capital markets as a source of uncertainty}

This class of models posits the existence of private investors that are motivated by rumors, noise trading, band wagons, bubbles, and so forth. In a way these are the most straightforward arguments in favor of capital controls. In this case the capital flow is itself the source of the disturbance to the competitive equilibrium. It follows that controlling these kinds of capital flows restores a first-best competitive equilibrium. The difficulty, of course, is to discriminate in the capital control program between stabilizing and destabilizing capital flows.

One of the oldest traditions in international finance is that just such a distinction is possible. The assertion is that short-term capital flows, or more precisely, capital flows with short holding periods, are distortions while long-term capital flows and direct investment are based on fundamentals. Keynes, for example, made the distinction between enterprise and speculation. If distorting capital flows are associated with short holding periods, it follows that a transactions tax will discourage distorting capital flows.

Tobin (1978) proposed such a tax and Eichengreen, Tobin, and Wyplosz (1995) update the argument. The basic idea is that adjustment in international goods and labor markets is slow and restricted and "when some markets adjust imperfectly, welfare can be enhanced by intervening in the adjustment of others" (page 164). An important aspect of the argument that distinguishes this from the other distortions reviewed above is that a turnover tax is designed to slow the adjustment speed of capital flows and the exchange rate, but not to distort the stock of net flows or the level of the exchange rate over the long run. The authors recognize that a transactions tar on foreign exchange trading would have to be universal but argue that an international organization such as the IMF could take on such a task. Eichengreen, Tobin, and Wyplosz also advance a quite different argument in favor of temporary tazes on banks' foreign lending based on a model of self-fulfilling speculative attacks. This argument is taken up below.

In commenting on this paper Garber and Taylor (1995) review familiar arguments concerning the difficulty in administering such a tax and add the idea that taxing transfers of bank deposits would be ineffective since swaps of securities and other "synthetic" transactions are now very well-developed components of international transactions.

Dornbusch (1986) emphasizes the important point that controls designed to slow down capital flows, in this paper dual exchange markets, can only be used as a "strictly transitory policy" to offset shocks to capital markets. The model developed by Dornbusch restates the familiar theme that in the 
long run, a control program that attempts to mask an inconsistent policy regime will generate increasing distortions and ultimately fail to preserve the regime. In cases where deviations between controlled and financial exchange rates have become large the "resource allocation costs outweigh any macroeconomic benefits" (page 22). This is partiy due to the realistic assumption that large differentials generate leakages of some commercial transactions to the free market. The political economy question is whether controls put in place to shield the real economy from financial shocks are likely to eventually generate misalignment in levels of exchange rates and interest rates that are politically difficult to correct.

Van Wijnbergen (1985) provides a more explicit link between variability of government policies and less than optimal domestic investment. The unnecessary variance causes underinvestment because investors will value the option of waiting until the uncertainty is resolved. Tornell (1990) develops a model in which the increased variance resulting from private capital transactions results in less that optimal real investment because investors value the option to wait till more settled times before making irreversible real investments in a country. Finally, Aizenman and Marion (1993) provide some evidence that uncertainty has a measurable negative effect on capital formation in developing countries.

\section{Domestic capital market distortions}

In the absence of a formal model involving capital controls, an often discussed distortion in both domestic and international financial markets arises from government insurance of the liabilities of domestic financial intermediaries. The most obvious example of this is deposit insurance for banks, but even in the absence of formal insurance, governments frequently intervene to protect creditors of institutions that are believed to be "too large to fail". The usual reason for such intervention is to prevent "contagion" of doubts about the solvency of large institutions from generating runs on solvent institutions and associated general declines in asset values.

The well-known problem with this policy is that it encourages financial institutions to reach for risk. The argument is simply that profits from favorable outcomes are paid out to owners of the institution while losses are shared with the government. The usual prudential regulations designed to limit the government's exposure to losses include requirements that the institution maintain adequate capital, that is, that current accounting profits are not immediately paid to equity holders, and various restrictions on the nature and concentration of assets held.

There is nothing unique about international capital flows in this context except that new types of assets and therefore new types of risks are opened to insured intermediaries when they are given access to international capital transactions. Mathieson and Rojas-Suarez (1993) argue that opening markets can generate important efficiency gains but that "potential official. credit risks arising from the institutional failures that can be created by 
the mispricing of risk or widespread fraud provide a strong case for improving the domestic system of prudential supervision" (pages 343-344). Dooley (1995) argues that commercial banks in the United States acquired claims on individual developing countries in the 1970 s that exceed the concentration ratios that were enforced for domestic lending. The problem was that regulators did not enforce country lending limits, a decision that was justified by the erroneous view that loans to many entities within a country provided a diversified portfolio. Kane (1995) argues that the unwillingness of the authorities to force a write-down of debt following the 1982 debt crisis validated the assumption that the government would provide "free" equity to insured institutions in the event of a bad outcome for their investments.

Akerlof and Romer (1993) argue that exchange risk provides a vehicle for banks to exploit government insurance in developing countries. Using Chile during the 1979-81 time period as a possible example, they argue that the expectation that the peso might be devalued led domestic firms and domestic banks to enter into dollar-denominated loans at interest rates that did not fully reflect the risk that the firms would be unable to repay the dollar liability in the event of a devaluation of the currency.

6. Sequencing of liberalization of capital markets and trade in goods and services

Governments considering liberalization of their capital markets are frequently also considering liberalization of trade in goods and services. This raises the possibility that it might be optimal to sequence the liberalization rather than liberalizing all markets simultaneously. This is a difficult area for formal modeling because it requires an explicit dynamic framework. The literature surveyed above focused on several possible sources of expected relative price changes associated with structural reform that might influence intertemporal choices of residents of a country undergoing a reform program. Opening the capital account might either mitigate or magnify the distortion inherent in such anticipated relative price changes.

The distortions that have attracted attention in the context of structural reform include real exchange rate changes associated with liberalization of trade restrictions, slow adjustment of labor markets to changes in relative prices of traded and nontraded goods, and, finally, expected relative price changes generated by reforms that are expected to be temporary.

As argued above, distortions in relative prices due to trade restrictions can generate a role for capital controls under some circumstances. But the sequencing issue is much more complicated. First, there is no very clear reason for the government to have to choose to liberalize one market at a time or to liberalize markets slowly. It is possible that it will take some time to dismantle trade restrictions, perhaps because of administrative problems or because the government wishes to spread out the 
impact on protected sectors over time. Similar reasoning might also apply to capital markets. If such constraints are taken as given, it is then possible to evaluate the sequencing problem. It should be recalled however, that the formal models do not provide a rationale for gradual decontrol.

An early argument along these lines is found in McKinnon (1973). Relaxation of trade restrictions would, other things being equal, generate a depreciation of the real exchange rate while relaxation of the capital account is assumed to call for an appreciation of the real exchange rate, given that capital controls had effectively limited desired inflows of capital. This "competition of instruments" problem is resolved by delaying liberalization of the capital account until trade and other distortions are eliminated.

Edwards and van Wijnbergen (1986) develop two ideas that are useful in this area. First they show in a static model that capital account liberalization in the face of trade distortions can be welfare reducing. The intuition is that tariffs can distort investment decisions and capital controls can, in principle, offset this distortion. They also develop a two period model where capital inflows are constrained. In this case gradual liberalization of the trade account generates expected changes in relative prices that can distort investment decisions.

Calvo (1988) develops the idea that any government policy that affects relative prices, and is expected to be temporary, is equivalent to a distortion of intertemporal relative prices. For example, temporary tariff reform implies that the relative prices of traded goods will change when the liberalization program is abandoned. In general it follows that liberalization of the capital account is not a good idea in cases where the government really has reformed but the private sector does not find the comitment credible.

Edwards (1989) provides an excellent summary of this literature and a model that attempts to pull together a number of distortions in order to provide some guidance for policy. Not surprisingly, when working with multiple initial distortions it is difficult to evaluate the welfare implications of alternative sequences of reform. Indeed, an important implication of the model is that the first-best solution is to liberalize all markets immediately.

Quirk (1994) argues that experience with developing countries indicates that simultaneous liberalization is both feasible and manageable given the right combination of other policies. The lesson, perhaps, is that the practical usefulness of the second-best argument is limited to those cases where one preexisting distortion is clearly dominant and for some good reason can be removed only over time. For example, countries with a record of failed structural reforms might focus on the distortion caused by lack of credibility of their efforts and the time it will take to convince market participants that the reform is permanent. 


\section{Multiple Equilibria and First-Best Arguments}

Turmoil in the ERM that emerged in 1992, and that continues today, has generated a resurgence in interest in models of "self-fulfilling" speculative attacks. It has long been recognized that changes in the policy regime that are expected to prevail following a successful attack can generate a successful speculative attack even if the government follows fully consistent policies preceding the attack.

A more stringent condition for a self-fulfilling attack is that the change in the exchange rate regime itself generates a "fundamental" change in the optimal path for monetary policy. If the private sector expects a more expansionary monetary policy following a successful attack it is possible that such expectations can generate a collapse of a system that is otherwise fully viable. Finally, a much more stringent condition is that a plausible model of the government's behavior implies that a change in policy following a successful attack is optimal given the change in the economic environment generated by the attack.

The lesson from these models is that the exchange rate regime is secondary to the monetary policy the government is expected to pursue, not just in the short run, but over the indefinite future. If the speculative attack is interpreted by the private sector as a signal that the government will also abandon monetary restraint in the future then, by the usual arguments, speculation in financial markets will result in capital movements today in anticipation of this perhaps distant event. It seems to follow that capital controls might significantly slow the onset of the attack. Moreover, an optimistic assessment of the potential role of capital controls might be that the conditions that generate the multiple equilibrium will change. For example, the government might find a way to recommit to not altering its behavior following an attack.

It is ironic that the first clear statement of these issues was heavily conditioned by the warning that an announced commitment to a regime, in this model a commodity "standard" rather than an exchange rate "standard", was unlikely to alter the private sector's expectations about monetary policy over the long run. Flood and Garber (1984) is worth repeating at length. "Behind the sequential transitions from one monetary regime to another... must lie a political economy that we have ignored. Such political economic forces determine the complete dynamic panorama of the monetary process... A commodity system can be interpreted as a discipline imposing rule only if the commodity standard's permanence is somehow guaranteed. As there is no means to ensure such performance, the notion of a commodity standard as a stabilizing rule is a chimera" (page 105).

Flood and Garber (1984) and Obstfeld (1986) show that if governments are assumed to follow more expansionary monetary policies following a successful speculative attack on the fixed exchange rate regime, policy regimes that are otherwise viable can be forced to collapse by selffulfilling private expectations. Obstfeld (1994) refines the argument by 
specifying the political economy that might account for the government's behavior before and after an attack. The analysis sets out a rational government that seeks to makimize a plausible objective function. Since the government's objectives are the same in any exchange rate regime it follows that policy setting under different regimes must reflect changes in the economic environment rather than arbitrary assumptions concerning the government's behavior.

Both models suggest that the source of self-fulfilling speculative attacks are multiple equilibria consistent with a given set of fundamentals. The first model develops the idea that private expectations concerning devaluation generate high domestic interest rates for long maturity government bonds in the first period of a two period model. High domestic interest rates generate a larger fiscal deficit carried into the second period. The government in the second time period minimizes a loss function that balances a higher tax rate on income against a higher ta: rate on money balances, that is, a higher rate of money creation and inflation. Given the large fiscal deficit, the government chooses to inflate, thereby validating the private sector's expectations. If the government could commit to a low rate of inflation, the nominal interest rate would fall in the first period, the fiscal deficit fall, and the optimal inflation rate in the second period would be low, again validating private expectations. An interesting feature of this model is that the government could avoid the commitment problem by denominating all its debt in foreign currency.

A second model assumes that government values price stability and the ability to offset negative shocks to output. A sudden shift in expectations concerning the government's preferences for full employment can trigger an attack on a regime which is viable under different expectations. These models are interesting because the government's decision to abandon the peg is fully consistent with an objective function that is the same under both regimes. The only thing that changes over time is private expectations concerning the viability of the regime.

Eichengreen and Wyplosz (1993) and Portes (1993) argue that selffulfilling models offer a reasonable interpretation of recent ERM crises. Their general point is that the ERM members that were forced to abandon their exchange rate commitments played by the rules of the game for a viable system as long as entry into the European Monetary Union was a feasible objective.

Eichengreen and Wyplosz argue that the benefits of membership in a European Economic Union made it rational for governments to pursue conservative monetary policies. An important condition for membership was the maintenance of a stable exchange rate for two years preceding membership. Thus, a successful attack made membership in the first round impossible and perhaps implied that future membership would be more costly to attain. Once this opportunity was removed by a successful speculative attack on the 
currency, it was then rational for the authorities to relaz monetary policy. Thus, the speculative attack generated the subsequent government behavior that validated the attack.

To buttress this interpretation, Eichengreen, Rose, and Wyplosz (1994) offer empirical evidence that the fundamentals behaved differently in the months leading up to ERM crisis as compared to a sample of crises in other fixed exchange rate regimes. In particular, they argue that the ERM crisis was not preceded by excessive money growth, growth in domestic assets, fiscal deficits, or a number of other variables usually associated with inconsistent policies.

A weakness in their interpretation of the evidence, as the authors acknowledge, is that a variety of factors might rationally lead to an expected change in the government's behavior but leave no evidence leading up to the attack. In particular they consider, but are not persuaded by, the possibility that rising unemployment associated with tight monetary policy in Germany might have generated expectations that monetary policy in other countries would be eased in the future as the political cost of unemployment accumulated.

The role of capital controls in preventing self-fulfilling speculative attacks seems obvious. It is plausible that effective controls would delay the end of a regime that suffered a spontaneous change in private expectations. If the regime remained vulnerable through current account transactions, the extended life for the good equilibrium made possible by capital controls would presumably be desirable. This assumption is reinforced if it is assumed that the ultimate destination for the regime is a credible common currency.

Nevertheless, the contrary argument is equaliy plausible. If the private sector knows that the system is protected by controls, they would be less impressed by observed stability. Lane and Rojas-Suarez (1992), for example, argue that the use of controls has ambiguous implications for credibility of a monetary policy regime.

The role of capital controls is also problematic because selffulfilling attacks can go the opposite direction. For example, a spontaneous decline in private inflationary expectations could set in motion a sequence of falling interest rates and fiscal deficits that generate a good equilibrium. It is perhaps informative that there seem to be few examples of changes in private expectations generating self-fulfilling virtuous responses by governments. Countries that start from a bad equilibrium should shun capital controls since they would delay adjustment to the new more optimistic private expectations.

A number of papers have exploited the idea that controls themselves might be powerful signals concerning the government's future policies. Dellas and Stockman (1993) show that a speculative attack might be generated by the expectation that capital controls will be introduced. If the 
government can commit not to introduce controls the fixed rate regime is sustainable. In this model a regime that is otherwise viable becomes vulnerable to expectations that controls will be imposed in response to the attack. This increases interest rates before the attack and generates the conditions for a self-fulfilling devaluation.

Laban and Larrain (1993) argue that removing controls on capital outflows generates capital inflows because controls on outflows make investment irreversible. Thus, by altering expectations concerning the terms on which investments can be reversed, the decontrol of capital flows helps generate welfare-increasing capital inflows.

Bartolini and Drazen (1994) develop the idea that controls themselves are a signal that affects private sector expectations concerning the government's future treatment of investors. In their model the removal of controls signals to investors that the government is less likely to tar foreign capital income, or reimpose controls once the capital inflow is in place.

Finally, obstfeld (1986) shows that capital controls can generate multiple equilibria where none exist with capital mobility. In this model multiple equilibria are a feature of a maximizing model with effective capital controls. Residents of the controlled economy maximize the utility of real money holdings and consumption over time subject to their balance sheet constraint. Owing to effective capital controls residents can accumulate real money balances only through current account surpluses, which have as a mirror image increases in the central bank's net foreign assets. Because the net foreign asset position of the central bank earns the world interest rate, a current account surplus generates an increase in the expected permanent income of residents. An unstable equilibrium occurs if the increase in real money balances, and the associated increase in expected income, is not more than matched with an increase in current consumption. If not, the current account surplus increases and money balances and income continue to rise until a stable equilibrium is reached. This is not an argument for or against capital controls. It only demonstrates that when the domestic interest rate is distorted through a capital control program the usual assumptions that generate convergence to a unique steady state equilibrium are not sufficient.

This literature presents a genuine problem for the policy implications of capital controls. On the one hand, an effective capital control program might buy enough time for the government to move the fundamentals to a region where self-fulfilling speculative attacks are less likely. The implication seems to be that controls might be a temporary measure to buy time for a virtuous government to establish its reputation. On the other hand, it is easy to show that the fact that controls might be introduced in the future can generate attacks where none would be observed otherwise. Finally, the removal of controls on capital outflows might be interpreted by the market as a commitment not to penalize foreign investors and therefore generate capital inflows. 
A practical implication of this type of model is that the government probably must be prepared to maintain its fundamental policy stance even if it is temporarily forced to abandon the exchange rate peg. This may involve significant short-run costs in terms of employment or distorting taxes necessary to finance debt service payments on domestic debt. Unfortunately, the role of capital controls in reducing the costs of maintaining the fundamentals is much less clear. On the surface it appears that controls might delay or even prevent a speculative attack and the associated costs. But the typical policy of imposing controls as the attack occurs, probably because the authorities believe that the controls are not effective for long, can also be a powerful force to trigger speculative attacks. Finally, a careful treatment of expectations can suggest that policies designed to limit net capital inflows might have just the opposite effect.

\section{Evidence on Effectiveness and Objectives of Controls}

Empirical work on the "effectiveness" of capital controls has suffered from the lack of a widely accepted definition of what constitutes an effective control program. At one end of the spectrum, evidence of effectiveness has been defined as the ability to detect over extended time periods different average behavior of selected economic variables for countries with and without capital control programs. At the other extreme, effectiveness has been defined as the ability to maintain an inconsistent macroeconomic policy regime forever.

For this reason observers have examined the same or similar data sets and reached very different qualitative conclusions concerning the "effectiveness" of controls. Those who see controls as a short-term device to allow the government time to react and adjust other policy tools generally argue that controls can be effective. Those who study the collapse of regimes and observe that these events are often preceded by the imposition of controls argue that controls are not effective.

The reading here of the extensive empirical literature for the industrial and developing countries is that it generally supports the conclusion that governments can drive a "small" wedge between domestic and international yields on similar short-term financial instruments for extended time periods. This is similar to the conclusions of recent surveys by Epstein and Schor (1992) and obstfeld (1995). Thus, capital control programs have had measurable "effects" on economic variables. Control programs have also generated "large" yield differentials for a few weeks or months but these seem to diminish over time as the private sector invests in techniques to avoid the controls.

The more important issue is whether or not these yield differentials are large enough and last long enough to enhance the "effectiveness" of a policy regime in attaining the government's economic objectives. 
Unfortunately, effectiveness in this sense cannot be evaluated without a structural model of what the government is trying to accomplish and the economic constraints it faces.

Perhaps the most direct evidence for the effects of a control program in the very limited sense described above is the spread between the commercial and financial spot exchange rates in dual exchange rate systems. Gros (1988) reports the spread for the Belgian franc over the 1979-87 time period and the Mexican peso from 1982-86. His interpretation of both these data sets is that the authorities were able to sustain a sizable differential for about one year before the private sector found ways to avoid the controls.

Cairncross (1973) provides data for the United Kingdom investment currency market from 1961-72. This data indicates that the control system was effective in the narrow sense in that the investment currency premium remained in excess of 20 percent for several years and at times reached nearly 50 percent. Nevertheless, Cairncross finds little evidence that the intended restriction on private capital outflows was effective. Cairncross and others also looked for evidence of controls instituted by the United States to control private direct investment and portfolio capital outflows resulted in lower private capital flows, but were unable to find such evidence. For these episodes the fact that alternative forms of capital flows were not controlled seemed to render the controls ineffective.

For currencies with extensive offshore markets for bank deposits another simple and informative test of the effects of controls is a comparison of returns on domestic bank deposits and similar deposits offered by offshore branches of the same or very similar banks. An early attempt to measure the effectiveness of controls using this data is reported in Dooley and Isard (1980). This paper presents a model in which onshore and offshore interest rates on bank deposits denominated in the same currency are related to the extensive capital controls program introduced by the German government over the 1970-74 time period and to the risk that such controls might be intensified. A problem for tests of the effectiveness of control programs is that they are complicated legal programs that are difficult to quantify. In this paper the controls are quantified according to a qualitative evaluation of the size of penalties or taxes on individual types of transactions as well as the extensiveness of the controls in terms of the types of transactions subject to control. This data suggests that the authorities managed to generate a 4 percentage point differential for a brief time during which virtually all private capital inflows were prohibited.

In this respect the controls had clearly measurable effects. Nevertheless, a speculative attack on the currency generated a very large-by 1970 s standards--increase in Germany's international reserves and the fixed exchange rate was abandoned. As the models reviewed above suggest, the control program does appear to have slowed down the demise of the system but could not preserve the par value system. 
Gros (1987) reports spreads between Euro and domestic deposits for Italy and France from 1979-86. He interprets these differentials, that were for short time periods as high as 20-24 percentage points, as consistent with his model that predicts that controls are temporarily effective in restraining large changes in investor's positions. That is, during times of turbulence in the ERM, private speculators were not able to adjust their open positions costlessly. Nevertheless, over longer horizons the interest differentials rapidly returned to very low levels.

Similar evidence for five industrial countries from 1982-92 is reported in Obstfeld (1994). He concludes that for industrial countries the links between on- and offshore markets are very close but that, "The data also show that actual or prospective government interventions remain a significant factor in times of turbulence" (page 17). This data decisively rejects the view that capital controls are always ineffective. But the data also suggests that either the governments involved quickly removed the incentives for speculation, through policy changes, or that speculators simply retreated to await another attack."

Chinn and Frankel (1994) report covered differentials for a group of developing countries in Asia. They find that these markets are not as integrated as the industrial countries but that during the 1980 s covered differentials seem to have narrowed even though capital controls were generally utilized by the countries studied.

Melvin and Schlagenhauf (1985) extend this approach by explicitly modeling the threat of controls or government-enforced default in addition to controls already in place. They find that for Mexico in the early 1980s, controls had a significant effect on capital flows. In considering the same episode Spiegel (1990) also finds that political risk was important but estimates it to have the opposite sign of that reported in Melvin and Schlagenhauf. Both papers indicate that the controls in place were effective.

Browne and McNelis (1990) provide a careful study of the imposition of controls over capital flows in Ireland from 1979-86. Forward exchange rates are available for this data set and the study is unusual in that it considers a number of domestic and international interest rates. The relative importance of domestic monetary conditions and the yield on similar UK instruments are compared before and after the imposition of controls in December 1978.

Their results suggest that there was a jump in the importance of domestic monetary factors in determining some interest rates in Ireland immediately after controls were imposed. However, as with the other studies, the effects of monetary conditions were short-lived, on average only about six months. The usual story emerges that the central bank gained some independence for a short time. 
The evidence also suggests that interest rates in domestic financial markets that are poorly integrated with other domestic markets are much more sensitive to domestic money shocks than are bank deposit markets. For example, Browne and McNelis find that changes in "domestic" monetary conditions had no impact on yields on bank deposits. Yet they find significant influence for domestic conditions on rates of return in relatively noncompetitive domestic loan and mortgage markets.

Fieleke (1994) compares short-term Euro interest rates to similar domestic interest rates for Spain, Ireland, and Portugal during the 1992 ERM crisis. In each case the authorities enforced controls on capital outflows as part of a defense of the exchange rate arrangement. Although the controls did result in measurable deviations between onshore and offshore interest rates, in the end controls did not prevent a change in the exchange rate.

Fieleke also points out that ERM members that did not utilize controls, Norway and Sweden, experienced much larger fluctuations in domestic interest rates in trying to maintain their exchange rate targets. He concludes that, "...it may be that Spain and Portugal did acquire some temporary insulation" (page 34).

Fieleke offers an interesting alternative test of the expected efficacy of controls by comparing the prices of equities for traded and nontraded goods industries leading up to the exchange rate crisis. If controls are expected to fail in the sense that there is no change in the probability of devaluation, the market value of nontraded goods industries should not rise following an unexpected imposition of controls. Data for Portugal during 1992 and 1993 offers conflicting evidence. The value of nontraded goods equities did rise relative to export-oriented industries but declined relative to import-competing industries. The short sample period and difficulty in identifying the orientation of firms clouds the results.

Eichengreen, Rose, and Wyplosz (1994) challenge this interpretation of the ERM experience. They make the point that focusing on actual devaluations biases the sample toward episodes in which capital control programs have failed. To overcome this, they examine the behavior of a number of economic variables during crisis and noncrisis periods to see if there are systematic differences in the experience of countries with controls as compared to countries without controls. This they argue is a more useful measure of the "effectiveness" of controls. During crisis periods countries with controls experienced higher inflation, higher rates of money growth, and higher growth of domestic assets. Controls did not seem to affect the loss of reserves, interest rate differentials, or fiscal imbalances. During noncrisis periods, controls appear to affect all the macroeconomic variables tested except reserves.

Their conclusion is quite consistent with the literature surveyed above. "Controls do not allow countries which pursue policies inconsistent with a peg to keep their exchange rate unchanged forever. They do not 
prevent attacks, nor do they permit countries to avoid reserve losses or interest rate increases when attacks occur. Controls merely render expansionary monetary policies viable for a longer period by attenuating the link between crises and exchange rate regime collapse" (page 8).

An important limitation of this methodology is that well-developed forward exchange markets or offshore deposit markets are needed to control for expected exchange rate changes. For many markets where liberalization is now a policy option, historical controls have inhibited the development of such markets. Thus, empirical research must rely on an alternative estimate of expected exchange rate changes.

Phylaktis (1988) reports results for Argentina based on the model discussed above but uses realized spot rates as a proxy for expected changes in exchange rates. Some types of controls were found to influence the uncovered interest differential. The interesting aspect of these results is that the existence of controls might have contributed both to effective taxation of foreign assets, to a political risk premium, and perhaps to the exchange risk premium. The difficulty in sorting out these effects in the absence of forward exchange markets has led researchers to explore alternative models.

Edwards and Khan (1985) propose a direct test for the relative importance of a domestic interest rate and an uncovered foreign rate in determining the demand for money. They found that for relatively open economies (Singapore) only the uncovered foreign expected yield was important in determining money demand. For countries with controls (Colombia) both the foreign rate and domestic "market clearing" rates were important.

Haque and Montiel (1990) develop an empirical test for developing countries for which market clearing domestic interest rate data is not available. This research utilizes an instrumental variable approach to control for the endogeneity of the observed monetary base. The authors conclude that the degree of capital mobility among developing countries is quite high and argue that this indicates that the pervasive controls over capital flows in place in most of the countries studied provided little scope for an independent monetary policy.

Dooley and Mathieson (1994) extend this model in order to test for changes in the degree of capital mobility over time. They also find that capital is quite mobile for countries that have extensive control programs and that in most cases this degree of mobility has increased over time. In general, this line of research suggests that control programs in developing countries have been of limited effectiveness.

Other authors using similar techniques have reported mixed results. Reisen and Yeches (1991) utilize curb market rates as a measure of effective domestic interest rates and find that capital mobility remained roughly constant for a group of Asian countries while Faruqee (1991) finds that 
integration between developing countries in Asia and Japan seems to have increased in recent years. Kwack (1994) develops such a model that identifies the exogenous part of the change in the base using a policy reaction function and reports plausible estimates of the effectiveness of Korean capital controls.

Each of the papers discussed above attempts to measure a counterfactual monetary base that the authorities are assumed to set for an extended time period. However, the observed change in the domestic part of the monetary base is some combination of the exogenous policy change and the response during the time period studied to offsetting private capital flows. Since the response to a policy-induced change in the monetary base can be literally instantaneous, it is difficult to identify the policy-induced part of observed changes short of developing a complete model of government behavior. It appears to be the case that different techniques for dealing with the endogenous nature of the regressors have important consequences for the results of these studies.

Edwards (1989) provides a qualitative evaluation of capital control programs leading up to 34 devaluations in developing countries. He concludes that governments typically intensified their control programs in the year before devaluations. He also reports data on premia in financial exchange markets as devaluations approached. While there are exceptions, in most cases the financial rate premia increased sharply in the one to three months before the exchange crisis led to devaluation. Nevertheless, data for these same episodes shows that current accounts weakened and reserve assets declined in spite of the controls. Edwards concludes that, "At most one can argue that these heightened impediments to trade managed to slow down the unavoidable balance of payments crisis unleashed by the inconsistent macroeconomic policies" (pages 189-190). This evidence seems consistent for the more thoroughly researched data for industrial countries.

1. Direct measures of capital flows

Johnston and Ryan (1994) examine the effects of capital control programs for recorded capital flows (including errors and omissions) for a cross section of 52 developing and industrial countries for the period 1985-92. An important difficulty with this approach is that controlling for factors other than capital controls that shape the structure of capital flows is quite difficult. As the authors point out, models of the capital account typically relate economic fundamentals, such as yield differentials and changes in wealth, to total net capital flows that is the mirror image of the current account balance. Within this constraint, the composition of the capital account between net official flows and net private flows then depends on the behavior of the government. If that behavior is not consistent over time, the behavior of net private capital flows will not be related to economic fundamentals. Moreover, to the extent that control programs respond to capital flows, it would not be surprising to observe that new controls over capital inflows are associated with increased inflows. 
Nevertheless, some interesting empirical regularities emerge from the data. The removal of controls on capital outflows by industrial countries did seem to influence the overall volume and structure of net private flows. Direct investment and recorded long-term portfolio investment seems to have been quite sensitive to changes in control programs. In contrast, control programs in developing countries do not seem to have affected either overall private capital flows or their composition. The authors reach the plausible conclusion that the administration of control programs in developing countries has been less effective as compared to industrial countries.

A related empirical literature has attempted to measure private capital outflows from developing countries that are not captured by balance of payments reporting systems. Such outflows, generally identified as capital flight, are presumed to be unrecorded because the residents of these countries wish to avoid legal restrictions on outflows and/or taxes on earnings from legal outflows. Dooley (1988) tests the idea that such flows reflect efforts of residents to avoid financial repression.

Mathieson and Rojas-Suarez (1994) test the relationship between capital flight capital control programs and other fundamental determinants of capital flight. They find that during episodes where capital flight responds to increased risk from inflation and default risk, countries with capital controls did not prevent capital flight. The private sector's reaction to a deterioration of the fundamentals was delayed.

Kamin (1988) develops a related idea that capital movements are concealed by misinvoicing of trade transactions. A case study of the Argentine dual exchange rate mechanism during the 1981-90 period, Kamin (1991), suggests that controls were made ineffective through export underinvoicing and a variety of other leakages.

\section{Tests of the political economy of capital controls}

Recent empirical work has attempted to relate countries' use of capital market restrictions to a variety of structural characteristics of the economy. This literature views policy regimes as endogenous responses to institutional and political features of the economy. Alesina, Grilli, and Milesi-Ferretti (1994) test the relevance of a number of rationalizations for the use of capital controls outlined above by looking for common characteristics of OECD countries that seem to be related to the utilization of controls. Their reading of the theoretical literature suggests that the use of controls should be related to the exchange rate regime, to the desire to tax capital income, and to the desire to tax money balances. They find that highly managed exchange rate regimes seem to be associated with the use of controls.

Preferences for taxing capital income and money balances are, in turn, related to a variety of attributes of the political system. For example, inflation might result from weak governments that cannot enforce other types of taxes or strong governments that decide to tar capital income. 
Governments with independent central banks might resist both inflation and controls designed to preserve the inflationary ta: base. Their findings suggest that countries with strong governments and dependent central banks are likely to utilize controls, presumably to generate revenue from inflation and to reduce real debt service.

They also test the impact of controls on other macroeconomic variables. controlling for political stability, they find that controls have a negative effect on the stock of government debt. This is consistent with models discussed above that suggest that revenue from inflation is enhanced by controls and that domestic real interest rates kept below the world rate might limit debt service costs. The structure of the economy also seems to be an important determinant of the use of controls. The data also suggest that, controlling for initial income levels and political stability, controls do not seem to influence growth rates.

Grilli and Milesi-Ferretti (1995) find similar results for a sample of 61 developing and developed countries. In particular, over an extended time period countries with controls seem to experience high rates of inflation, relatively high shares of government revenue from seigniorage, and relatively low real interest rates. These recent results suggest that fiscal considerations are the most important determinants of the use of capital controls and that the controls, or some factor highly correlated with the use of controls, have measurable effects on government revenues.

\section{Integration and net capital flows}

The consensus from empirical work reviewed above is that capital markets of industrial countries and many developing countries are highly integrated and that integration has increased substantially over the past 30 years. Capital controls or dual exchange rate systems have been effective in generating yield differentials, covered for exchange risk, for short periods of time, but have had little power to stop speculative attacks on regimes that were seen by the market as being inconsistent.

It is surprising in light of this evidence that so little supporting evidence is found in the nonfinancial data. What has become known as the Feldstein-Horioka puzzle is the lack of real savings investment imbalances among countries with apparently integrated financial markets. As argued in Dooley et al. (1987), tests of savings-investment correlations are joint tests of several hypotheses, most of which have little to do with capital mobility or capital controls. The test of market integration might fail because purchasing power parity does not hold, exchange rate risk is a powerful barrier to international investment, domestic financial markets are poorly integrated, the economies studied are near a steady state in which imbalances are very small, or finally that government policies other than capital controls generate small current account imbalances. 
In a recent survey of this literature Obstfeld (1994) suggests that the puzzle is real in the sense that current account imbalances appear to be too small relative to historical periods when capital accounts were apparently open or to net capital movements within national boundaries. Several observers have concluded that the most plausible reason for this departure from the expected pattern of international investments is that governments have targets for the current account and manipulate macroeconomic policies to attain these targets. There appears to be no evidence that would suggest that capital controls are an important part of the apparent barriers to real capital mobility.

While not directly relevant to this paper's exploration of capital account restrictions, this observation is interesting and important. Recall that an effective control program is closely related to a government target for the current account balance. It seems clear that if governments are pursuing current account targets using other distortionary policy tools, that the welfare effects of imposing controls are much less clear. In this case the alternative to capital controls is not free trade in financial assets but distortion of another policy tool to eliminate private incentives for intertemporal trade.

A few studies of the real side evidence have looked directly at the effects of capital controls on real capital mobility. Razin and Rose (1992) created a measure of capital controls from the IMF's Annual Report on Exchange Arrangements and Exchange Restrictions and tested the impact of these controls for a cross section of industrial and developing countries. They tested the hypothesis that changes in consumption should be correlated among countries with open capital markets and investment should be more variable over time. None of these predictions is supported by the data. Like all these studies, these are tests of complicated joint hypotheses. But the data seems to support the view that while real capital markets may not be highly integrated, capital control programs do not seem to be the main reason for this fact.

\section{Gross capital flows and capital controls: theory and evidence}

The implicit assumption in literature reviewed in the previous section is that net capital flows, and the associated redistribution of savings and investment across countries, determine the welfare consequences of capital mobility. Gross private capital flows and the structure of international financial intermediation are by implication less important for evaluating the economic consequences of international capital flows and controls on these flows. This section suggests that such models ignore important considerations in the balance of costs and benefits of capital control programs.

Some of the literature already reviewed is relevant for gross capital flows but in general this subject is not well developed in the literature. Nevertheless, the evidence cited above suggests that the welfare gains from liberalization of international credit markets is likely to come from better 
utilization of available domestic savings rather than from net flows of foreign savings. The important point is that direct investment and other international capital transactions might be welfare improving even if no net capital flow is associated with free trade in financial services.

Obstfeld (1995) develops the idea that closed national credit markets might be very unlikely to finance high-risk investments because of risk aversion among domestic savers and the inability to diversify within the domestic markets. If high-risk investment projects also have relatively high payoffs in terms of endogenous economic growth, the closed capital market implies that the growth rate of the country is limited. Opening the capital account in this model allows nonresident investors with lower levels of risk aversion to hold high-return investments in the country while residents hold relatively safe foreign assets. Thus, with no net capital flow, domestic savings are channeled into investments that generate a higher growth rate. As demonstrated in a simulation exercise, the welfare benefits of a higher growth path can be very large.

Partial equilibrium models of the potential benefits for investors of greater access to equity markets in developing countries also suggests that significant welfare gains are available (Lesard, 1973; Harvey, 1994). These models employ an international capital asset pricing model to evaluate the possibility that opening equity markets would improve the risk return trade off faced by an investor currently limited to industrial country equities. Recent work has also tested the effects of restrictions on foreign investment as measured by an investability index compiled by the International Finance Corporation (Bekeart, 1993; Claessens, Dasgupta, and Glen, 1995). This analysis suggests that existing controls have had significant effects on yields of equities and that removal of such restrictions would benefit investors.

The apparent benefits from international diversification have also led to research that compares optimal portfolios to observed portfolios. While there are many problems with the data on gross international capital flows and even more problems with calculation of stocks of cross-border private financial claims and liabilities, this research suggests a very clear "home bias" in portfolios of residents of industrial countries. Tesar and warner (1992) report that residents of industrial countries hold almost all their wealth in the form of claims on residents of their home country. Golub (1990) argues that evidence from gross capital flows suggests that a very minor part of the capital stock of OECD countries reflects gross foreign ownership and concludes that this measure of capital mobility is even more puzzling than the data on current account imbalances discussed in the previous section. 


\section{Bibliography}

Adams, Charles, and Jeremy Greenwood, "Dual Exchange Rate Systems and Capital Controls: An Investigation," Journal of International Economics, Vol. 18 (1985), pp. 43-63.

Aizenman, Joshua, "External Debt, Planning Horizon, and Distorted Credit Markets," Journal of International Money and Finance, Vol. 9 (1990), pp. $138-158$.

, "On the Complementarity of Commercial Policy, Capital Controls, and Inflation Tax," Canadian Journal of Economics, Vol. 19 (February 1986), pp. $114-133$.

, and Pablo E. Guidotti, "Capital Controls, Collection Costs and Domestic Public Debt," Journal of International Money and Finance, Vo1. 13 (February 1994), pp. 41-54.

- and Nancy P. Marion, "Macroeconomic Uncertainty and Private Investment," Economic Letters, Vol. 41 (1993), pp. 207-210.

Akerlof, George A., and Paul M. Romer, "Looting: The Economic Underworld of Bankruptcy for Profit," Brookings Papers on Economic Activity, 2 (Washington: The Brookings Institution, 1993) pp. 1-60 and 70-74.

Alesina, Alberto, Vittorio Grilli, and Gian Maria Milesi-Ferretti, "The Political Economy of Capital Controls," in Leonardo Leiderman and Assaf Razin, eds., Capital Mobility: The Impact on Consumption, Investment, and Growth (Cambridge and New York: Cambridge University Press, 1994).

, and Guido Tabellini, "External Debt, Capital Flight and Political Risk," Journal of International Economics, Vol. 27, No. 3-4 (November 1989\}, pp. 199-221.

Auernheimer, Leonardo, "On the Outcome of Inconsistent Programs under Exchange Rate and Monetary Rules," Journal of Monetary Economics, Vol. 19 (1987), pp. 279-305.

Baccheta, Philippe, "Temporary Capital Controls in a Balance-of-Payments Crisis," Journal of International Money \& Finance, Vol. 9 (September 1990), pp. 246-257.

Bartolini, Leonardo, and Allan Drazen, "Capital Account Liberalization as a Signal," IMF Working Paper, (Washington: International Monetary Fund, November 1994\}.

Bekaert, Geert, "Market Integration and Investment Barriers in Emerging Equity Markets," Working Paper, Stanford Graduate School of Business, (1993). 
Bhandari, Jagdeep S., and Bernard Decaluwe, "A Stochastic Model of Incomplete Separation Between Commercial and Financial Exchange Markets," Journal of International Economics, Vol. 22 (1987), pp. 25-55.

Blackburn, Keith, and Martin Sola, "Speculative Currency Attacks and Balance of Payments Crises," Journal of Economic Surveys, Vol. 7, No. 2 (1993), pp. 119-144.

Branson, william, "Comment," H. Reisen and B. Fisher, eds., Financial Opening: Policy Issues and Experiences in Developing Countries, (Paris: Organization for Economic Co-Operation and Development, 1993).

Brock, Philip L., "Inflationary Finance in an Open Economy," Journal of Monetary Economics, Vol. 14 (1984), pp. 37-53.

Browne, Francis X., and Paul D. McNelis, "Exchange Controls and Interest Rate Determination with Traded and Non-Traded Assets: the Irish-United Kingdom Experience," Journal of International Money and Finance, Vol. 9 (1990), pp. 41-59.

Cairncross, Alec, Control of Long-Term International Capital Movements (Washington, D.C.: The Brookings Institution, 1973).

Calvo, Guillermo A., "Balance of Payments Crises in a Cash-in-Advance Economy," Journal of Money, Credit, and Banking, Vol. 19, No. 1 (February 1987), pp. 19-32.

, "Costly Trade Liberalizations: Durable Goods and Capital Mobility," Staff Papers, International Monetary Fund, Vol. 35, No. 3 (September 1988), pp. $461-473$.

Chinn, Menzie D., and Jeffrey A. Frankel, "Financial Links Around the Pacific Rim: 1982-1992," R. Glick and M. Hutchison, eds., Exchange Rate Policy and Interdependence: Perspectives from the Pacific Basin (Cambridge, Massachusetts: Cambridge University Press, 1994), pp. $17-47$.

Claassen, Emil-Maria and Charles Wyplosz, "Capital Controls: Some Principles and the French Experience," J. Melitz and C. Wyplosz, eds., The French Economy: Theory and Policy, (Boulder, Colorado: Westview Press, Inc., 19851, pp. 237-267.

Claessens, Stijn, "Balance-of-Payments Crises in a Perfect Foresight Optimizing Model," Journal of International Money and Finance, Vol. 7 (1988), pp. 363-372.

, S. Dasgupta and J. Glen, "Return Behavior in Emerging Stock Markets," World Bank Economic Review, Vol. 9, No. 1 (January 1995) pp. $131-151$. 
Delbecque, Bernard, "Dual Erchange Rates Under Pegged Interest Rate and Balance-of-Payment Crisis," Journal of International Money and Finance, vol. 12 (1993), pp. 170-181.

Dellas, Harris, and Oded Galor, "Growth Via External Public Debt and Capital Controls," International Economic Review, Vol. 33, No. 2 (May 1992), pp. 269-281.

, and Allan Stockman, "Self-Fulfilling Expectations, Speculative Attack, and Capital Controls," Journal of Money, Credit and Banking, Vol. 25, No. 4 (November 1993 ) pp. 721-730.

Dooley, Michael P., Jeffrey Frankel, and Donald J. Mathieson, "International Capital Mobility: What Do Saving-Investment Correlations Tell Us?" Staff Papers, International Monetary Fund, Vol. 34, No. 3 (September 1987).

- and Peter Isard, "Capital Controls, Political Risk, and Deviations from Interest-Rate Parity," Journal of Political Economy, Vol. 98, No. 2 (April 1980), pp. 370-384.

- "Capital Flight: A Response to Differences in Financial

Risks," Staff Papers, International Monetary Fund, Vo1. 35, No. 3 (September 1988).

, "A Retrospective on the Debt Crisis," P. Kenen, ed., Understanding Interdependence: The Macroeconomics of the open Economy (Princeton, N.J.: Princeton University Press, 1995).

, and Kenneth M. Kletzer, "Capital Elight, External Debt, and Domestic Policies," Economic Review, Vol. 3 (1994), pp. 29-37.

, and Donald J. Mathieson, "Exchange Rate Policy, International Capital Mobility, and Monetary Policy Instruments," R. Glick and M. Hutchison, eds., Exchange Rate Policy and Interdependence: Perspectives from the Pacific Basin (Cambridge, Massachusetts: Cambridge University Press, 1994), pp. 68-95.

Dornbusch, Rudiger, "Special Exchange Rates for Capital Account Transactions," The World Bank Economic Review, Vol. 1, No. 1 (1986), pp. 3-33.

, "The EMS the Dollar and the Yen," F. Giavazzi, S. Micossi and M. Miller eds. The European Monetary System, Cambridge (UK), Cambridge University Press, 1988.

Drazen, Allan, "Monetary Policy, Capital Controls and Seigniorage in an Open Economy," M. de Cecco and A. Giovannini, eds., A European Central Bank?: Perspectives on Monetary Unification After Ten Years of the EMS, (New York: Cambridge University Press, 1989) pp. 13-32. 
Edwards, Sebastian, "On the Sequencing of Structural Reforms," NBER Working Paper No. 3138 (Cambridge, Massachusetts: National Bureau of Economic Research, October 1989).

, Real Eachange Rates Devaluation and Adjustment (Cambridge: The MIT Press, 1989.)

, "Tariffs, Capital Controls, and Equilibrium Real Exchange Rates," Canadian Journal of Economics, Vol. 22, No. 1 (February 1989), pp. 79-93.

, and Mohsin S. Khan, "Interest Rate Determination in Developing Countries: A Conceptual Framework," International Monetary Fund Staff Papers September, 1985.

, and Jonathan Ostry, "Terms of Trade Disturbances, Real Erchange Rates, and Welfare: The Role of Capital Controls and Labor Market Distortions," Oxford Economic Papers, Vol. 44 (January 1992), pp. 20-34.

, and Sweder van Wijnbergen, "The Welfare Effects of Trade and Capital Market Liberalization," International Economic Review, Vol. 27, No. 1 (February 1986), pp. 141-148.

Eichengreen, Barry, Andrew K. Rose, and Charles Wyplosz, "Speculative Attacks on Pegged Exchange Rates: An Empirical Exploration with Special Reference to the European Monetary System," NBER Working Paper No. 4898 (Cambridge, Massachusetts: National Bureau of Economic Research, October 1994).

, James Tobin, and Charles Wyplosz, "Two Cases for Sand in the wheels of International Finance," The Economic Journal, Vol. 105 (January 1995), pp. 162-172.

, and Charles Wyplosz, "The Unstable EMS," Brookings Papers on Economic Activity, 1 (Washington: The Brookings Institution, 1993).

Epstein, Gerald A., and Juliet B. Schor, "Structural Determinants and Economic Effects of Capital Controls in OECD Countries," T. Banuri and J. Schor, eds., Financial openness and National Autonomy: Opportunities Constraints, (Oxford, England: Clarendon Press, 1992), pp. 136-161.

Faruqee, Hamid, "Dynamic Capital Mobility in Pacific Basin Developing Countries: Estimation and Policy Implications," IMF Working Paper 91/115 (November, 1991).

Fieleke, Norman S., "International Capital Transactions: Should They Be Restricted?" New England Economic Review, (March/April 1994), pp. 27-39 
Fischer, Bernhard, and Helmut Reisen, Liberalising Capital Flows in Developing Countries: Pitfalls, Prerequisites and Perspectives (Development Centre Studies), (Paris: Organization for Economic Cooperation and Development, 1993).

Flood, Robert P., and Peter M. Garber, "Gold Monetization and Gold Discipline," Journal of Political Economy, Vol. 92 (1984), pp. 90-107.

, and Nancy P. Marion, "The Transmission of Disturbances Under Alternative Exchange-Rate Regimes with Optimal Indexing," Quarterly Journal of Economics, (February, 1982), pp. 43-66.

Frankel, Jeffrey A., "Measuring International Capital Mobility: A Review," American Economic Review, Vol. 82, No. 2, pp. 197-201.

Garber, Peter M., and Lars E.O. Svensson, "The Operation and Collapse of Fized Exchange Rate Regimes," NBER Working Paper No. 4971 (Cambridge, Massachusetts: National Bureau of Economic Research, December 1994).

- and Mark P. Taylor, "Sand in the Wheels of Foreign Exchange Markets: A Skeptical Market," Economic Journal: The Journal of the Royal Economic Society, Vol. 105, No. 428 (January 1995), pp. 173-180.

Giavazzi, Francesco and Alberto Giovannini, Limiting Exchange Rate Flexibility: The European Monetary System (Cambridge, Mass: MIT Press, 1989).

Giovannini, Alberto, and Martha de Melo, "Government Revenue from Financial Repression," The American Economic Review, Vol. 83, No. 4 (September 1993), pp. 953-963.

, and Jae Won Park, "Capital Controls and International Trade Finance," Journal of International Economics, Vol. 33 (November 1992), pp. 285-304.

Golub, Stephen S., "International Capital Mobility: Net Versus Gross Stocks and Flows," Journal of International Money and Einance, Vol. 9 (1990), pp. 424-439.

Greenwood, Jeremy, and Kent P. Kimbrough, "Capital Controls and Fiscal Policy in the World Economy," Canadian Journal of Economics, Vol. 18, No. 4 (November 1985), pp. 743-765.

Grilli, Vittorio, and Gian Maria Milesi-Ferretti, "Economic Effects and Structural Determinants of Capital Controls," IMF Working Paper 95/31 (Washington: International Monetary Eund, March 1995).

, and Nouriel Roubini, "Liquidity, Capital Controls, and Exchange Rates," Journal of International Money and Finance, Vol. 12 (April 1993), pp. 139-153. 
Gros, Daniel, "Capital Controls and Foreign Exchange Market Crises in the EMS," (European Monetary System) European Economic Review, Vol. 36 (December 1992), pp. 1533-1544.

, "Dual Exchange Rates in the Presence of Incomplete Market Separation: Long-Run Effectiveness and Policy Implications," Staff Papers, International Monetary Eund, Vol. 35, No. 3 (September 1988), pp. $437-460$.

, "The Effectiveness of Capital Controls: Implications for Monetary Autonomy in the Presence of Incomplete Market Separation, " Staff Papers, International Monetary Fund, Vol. 34, No. 4 (December 1987), pp. 621-642.

Guidotti, Pablo E., and Carlos A. Vegh, "Macroeconomic Interdependence Under Capital Controls: A Two-Country Model of Dual Exchange Rates," Journal of International Economics, Vol. 32 (May 1992), pp. 353-367.

Guitián, Manuel, "Currency Convertibility: Concepts and Degrees," Seminar on Currency Convertibility sponsored by the IMF Institute and the Arab Monetary Fund (December 1993).

Haque, Nadeem Ul, and Peter Montiel, "Capital Mobility in Developing Countries - Some Empirical Tests," IMF Working Paper 90/117

(Washington: International Monetary Fund, December 1990).

Harberger, Arnold C., "Welfare Consequences of Capital Inflows," Armeane M. Choksi and Demetris Papageorgiou, eds., Economic Liberalization in Developing Countries (Oxford: Basil Blackwell, 1986) pp. 157-183.

Harvey, Campbell, R., "Predictable Risk and Relative Returns in Emerging Markets," NBER Working Paper No. 4621 (Cambridge, Massachusetts: National Bureau of Economic Research, October 1994).

Helpman, Elhanan, "An Exploration in the Theory of Exchange Rate Regimes," Journal of Political Economy, Vol. 89, No. 5, (1981) pp. 865-890.

Johnston, R. Barry, and Chris Ryan, "The Impact of Controls on Capital Movements on the Private Capital Accounts of Countries' Balance of Payments: Empirical Estimates and Policy Implications," IMF Working Paper 94/78 (Washington: International Monetary Fund, July 1994).

Kamin, Steven B., "Devaluation, Exchange Controls, and Black Markets for Foreign Exchange in Developing Countries," International Finance Discussion Papers, No. 334 (Washington: Board of Governors of the Federal Reserve system, october 1988).

, "Argentina's Experience with Parallel Exchange Markets: 1981-1900," International Finance Discussion Papers, No. 407 (Washington: Board of Governors of the Federal Reserve System, August 1991). 
Kane, Edward J., The Gathering Crisis in Federal Deposit Insurance (Cambridge: The MIT Press, 1995) pp. 119-128.

Krugman, Paul, "A Model of Balance-of-Payments Crises," Journal of Money, Credit, and Banking, Vol. 11, No. 3 (August 1979), pp. 312-325.

, "The Narrow Moving Band, the Dutch Disease, and the Competitive Consequences of Mrs. Thatcher: Notes on Trade in the Presence of Scale Economies," Journal of Development Economics, Vol. 27 (1987), pp. $41-55$.

Kwack, Sung Y., "Sterilization of the Monetary Effects of Current Account Surpluses and Its Consequences: Korea, 1986-1990," R. Glick and M. Hutchison, eds., Exchange Rate Policy and Interdependence: Perspectives from the Pacific Basin, (Cambridge, Massachusetts: Cambridge University Press, 1994), pp. 287-313.

Laban, R., and F. Larrain, "Can a Liberalization of Capital Outflows Increase Net Capital Inflows?" Pontificia Universidad Catolica de Chile, Instituto de Economia, Working Paper No. 155 (1993).

Lane, Timothy, and Liliana Rojas-Suarez, "Credibility, Capital Controls, and the EMS," (European Monetary System) Journal of International Economics, Vol. 32 (May 1992), pp. 321-337.

Lessard, Donald, "International Portfolio Diversification: A Multivariate Analysis for a Group of Latin Countries," Journal of Finance, 28, (1973) pp. 619-633.

Marston, Richard C., "Interest Differentials under Bretton woods and the Post-Bretton Woods Float: The Effects of Capital Controls and Erchange Risk," Chapter 11, A Retrospective on the Bretton woods System, ed. by Michael D. Bordo and Barry Eichengreen (Chicago: The University of Chicago Press, 1993).

Mathieson, Donald J., and Liliana Rojas-Suarez, "Liberalization of the Capital Account, Experiences and Issues," IMF Occasional Paper 103 (Washington: International Monetary Fund, March 1993).

McKinnon, Ronald, I., Money and Capital in Economic Development, (Washington D.C.), The Brookings Institution (1973).

Melvin, Michael, and Don Schlagenhauf, "A Country Risk Index: Econometric Formulation and an Application to Mexico," Economic Inquiry, Vol. 23, (October 1985), p. 601 .

Obstfeld, Maurice, "Capital Controls, the Dual Exchange Rate, and Devaluation," Journal of International Economics, Vol. 20 (1986), pp. $1-20$. 
, "Rational and Self-Fulfilling Balance-of-Payments Crises," The American Economic Review, Vol. 76, No. 1 (March 1986), pp. 72-81.

, "The Logic of Currency Crises," NBER Working Paper No. 4640 (Cambridge, Massachusetts: National Bureau of Economic Research, 1994).

, "International Capital Mobility in the 1990s," P. Kenen, ed., Understanding Interdependence: The Macroeconomics of the Open Economy, (Princeton, New Jersey: Princeton University Press, 1995).

, "Are Industrial-country Consumption Risks Globally Diversified?" Leonardo Leiderman and Assaf Razin, eds., Capital Mobility: The Impact on Consumption, Investment, and Growth (Cambridge and New York: Cambridge University Press, 1994).

- "Risk Taking, Global Diversification, and Growth," American Economic Review, 84, No. 5 (December 1995), pp. 1310-1329.

- and Kenneth Rogoff, "The Intertemporal Approach to the Current Account," NBER Working Paper No. 4893 (Cambridge, Massachusetts: National Bureau of Economic Research, October 1994).

Park, Daekeun, "Foreign Exchange Liberalization and the Viability of a Fixed Exchange Regime," Journal of International Economics, Vol. 36 (1994), pp. 99-116.

Phylaktis, Kate, "Capital Controls: The Case of Argentina," Journal of International Money and Finance, Vol. 7 (1988), pp. 303-320.

Portes, Richard, "EMS and EMU After the Fall," The World Economy, Vol. 16, No. 1 (1993), pp. 1-16.

Quirk, Peter J., "Capital Account Convertibility: A New Model for Developing Countries," Erameworks for Monetary Stability, T. Baliño and C. Cottarelli, eds. (Washington, International Monetary Eund, 1994).

Razin, Assaf, and Efraim Sadka, "Efficient Investment Incentives in the Presence of Capital Flight," Journal of International Economics, Vol. 31 (1991), pp. 171-181.

, and Andrew Rose, "Business Cycle Volatility and Openness : An Exploratory Cross-section Analysis," Leonardo Leiderman and Assaf Razin, eds., Capital Mobility: The Impact on Consumption, Investment, and Growth (Cambridge and New York: Cambridge University Press, 1994).

Reinhart, Carmen M., and R. Todd Smith, "Capital Controls: Concepts and Experiences," Mimeo (March 1995), pp. 1-32.

Reinhart, Vincent, "The 'Tobin Tax,' Asset Accumulation, and the Real Exchange Rate," Journal of International Money and Finance, Vol. 10 
(1991), pp. 420-431.

Reisen, Helmut, "Pension Funds, Capital Controls and Macroeconomic Stability," OECD Working Paper Vol, 2, No. 47 (Paris, France: Organisation for Economic Co-Operation and Development, 1994). , and Helene Yeches, "Time-Varying Estimates on the Openness of the Capital Account in Korea and Taiwan," Journal of Development Economics, Vol. 41, No. 2 (August 1991), pp. 285-305.

Spiegel, Mark M., "Capital Controls and Deviations from Proposed Interest Rate Parity: Mexico 1982," Economic Inquiry, Vol. 28 (April 1990), pp. 239-248.

Stockman, Alan C., and Alejandro D. Hernandez, "Exchange Controls, Capital Controls, and International Financial Markets," American Economic Review, vol. 78 (June 1988), pp. 362-375.

Sussman, Oren, "Financial Liberalization: The Israli Experience," Oxford Economic Papers, Vol. 44 (1992), pp. 387-402.

, "Macroeconomic Effects of a Tax on Bond Interest Rates," Journal of Money, Credit, and Banking, Vol. 23, No. 3 (August 1991, Part 1), pp. 352-366.

Tesar, Linda and Ingrid Warner, "Home Bias and the Globalization of Securities Markets," NBER Working Paper No. 4218 (Cambridge, Massachusetts: National Bureau of Economic Research, October 1992).

Tobin, J., "A Proposal for International Monetary Reform," Eastern Economic Journal, Vol. 4 (1978).

Tornel1, Aaron, "Real vs. Einancial Investment, Can Tobin Taxes Eliminate the Irreversibility Distortion?" Journal of Development Economics, Vol. 32 (1990), pp. 419-444.

Tornel1, Aaron, and A. Velasco, "The Tragedy of the Commons and Economic Growth: Why Does Capital Flow from Poor to Rich Countries?" Journal of Political Economy, Vol. 100, No. 6 (1992), pp. 1208-1231.

van Wijnbergen, Sweder, "Capital Controls and the Real Exchange Rate," Economica, Vol. 57 (February 1990), pp. 15-28.

, "Trade Reform, Aggregate Investment, and Capital Flight," Economic Letters, Vol. 19 (1985), pp. 369-372.

Williamson, John, "A Cost-Benefit Analysis of Capital Account Liberalization," H. Reisen and B. Fisher, eds., Financial Opening: Policy Issues and Experiences in Developing Countries, (Paris: Organisation for Economic Co-Operation and Development, 1993). 
Wyplosz, Charles, "Capital Controls and Balance of Payments Crises," Journal of International Money and Finance, Vol. 5 (1986), pp. 167-179. 